\title{
Peripheral Myelin Protein 22
}

National Cancer Institute

\section{Source}

National Cancer Institute. Peripheral Myelin Protein 22. NCI Thesaurus. Code C75902.

Peripheral myelin protein $22(160 \mathrm{aa}, \sim 18 \mathrm{kDa}$ ) is encoded by the human PMP22 gene.

This protein is involved in the determination of the structure and deposition of myelin. 